TITLE:

\title{
Ecology and Biodiversity of Rocky Intertidal Barnacles Along a Latitudinal Gradient; Japan, Taiwan and Hong Kong
}

\author{
AUTHOR(S):
}

CHAN, BENNY K.K.

\section{CITATION:}

CHAN, BENNY K.K.. Ecology and Biodiversity of Rocky Intertidal Barnacles Along a Latitudinal Gradient; Japan, Taiwan and Hong Kong. Publications of the Seto Marine Biological Laboratory. Special Publication Series 2007, 8: 1-10

\section{ISSUE DATE:}

2007

URL:

http://hdl.handle.net/2433/70915

RIGHT: 


\title{
Ecology and Biodiversity of Rocky Intertidal Barnacles Along a Latitudinal Gradient; Japan, Taiwan and Hong Kong
}

\author{
BENNY K.K. CHAN \\ Research Centre for Biodiversity Academia Sinica, \\ 128, Section 2, Academia Road, Taipei 115, Taiwan ROC \\ Author's e-mail: chankk@gate.sinica.edu.tw
}

\begin{abstract}
The life cycle of barnacles is composed of a planktonic larval and a sessile adult stage. As a result the geographical distribution of barnacles is influenced by a combination of ocean currents, settlement success and subsequent recruitments. Barnacles show different geographical distributions along the, latitudinal gradient that connects the North West Pacific and South China Sea. On the Pacific coast of Honshu Japan the high shore was dominated by Chthamalus challengeri (>70\% cover). South of Honshu in Okinawa the high tide zone was populated by Nesochthamalus intertextus and Hexechamaesipho pilsbryi. In Taiwan the high tide zone was colonized by $H$. pilsbryi, Chthamalus malayensis and C. moro. In Hong Kong the high tide zone was occupied by $C$. malayensis ( $>60 \%$ cover). The mid shores were all occupied by the genus Tetraclita. In the NW Pacific (Honshu, Okinawa and Taiwan), the common species were Tetraclita kuroshioensis, T. japonica japonica and T. j. formosana. In Hong Kong, only $T$. squamosa and T.j. japonica were recorded. The life history pattern of the barnacles in Hong Kong was seen to follow a seasonal trend not observed in the NW Pacific, in the warmer waters of Hong Kong early gonad development and settlement were followed by a regular summer die-off linked to heat and desiccation stress. Barnacles in Japan were found to have a shorter reproductive period and a longer life span than those in Hong Kong. Association with different ocean currents explains some of the difference in barnacle composition between Hong Kong and the NW Pacific, the rest is explained by the environmental and climatic changes along the latitudinal gradient and the ensuing differences of ecology and biodiversity found among the sites.
\end{abstract}

Key words: Barnacles, biodiversity, latitudinal gradient, life history patterns

\section{Introduction}

Barnacles form a dominant belt along most of the world's intertidal region (Reimer, 1976a). Being principal filter feeders in the intertidal food chain and a foundation species, they modify the habitat structure and affect the abundance and population structure of other intertidal organisms, and are vital to the ecological balance of the near shore system (Reimer, 1976b; Kawai and Tokeshi, 2004). The life cycle of barnacles is composed of planktonic larval and sessile adult stages. The distribution and population dynamics of barnacles are driven by the supply of larvae, larval behavior, settlement, post-settlement mortality and subsequent recruitment into the adult population (Jenkins et al., 2001; see review by Morgan, 2001). Climatic and oceanographic conditions including currents and upwelling events affect the geographical distribution of barnacles differently along latitudinal gradients (Connolly et al., 2001).

As the global climate changes (a trend escalating with the increasing influence of human activities in the natural environment) the larval supply, post-settlement mortality and geographical distribution of organisms in the intertidal ecosystem are altered. The global surface temperature has risen approximately $1^{\circ} \mathrm{C}$ in the past century and it is predicted to rise further over the next 50 years (Thompson et al., 2002). In the United Kingdom and the U.S.A., quantitative comparisons of the distribution patterns of the intertidal assemblages over the past 70 years show that the increase in 
temperature has enhanced the survival, distribution range and abundance of the warm-water barnacle species Chthamalus stellatus Poli and reduced the same for the cold-water species Semibalanus balanoides Linnaeus. This change has resulted in a shift of the vertical zonation, geographical distribution and gene flow between populations of intertidal organisms (Thompson et al., 2002). Global warming changes the thermal regimes of the intertidal area and alters the distribution and abundance of the intertidal communities. Understanding the geographical variation in the distribution and the population dynamics of intertidal communities is essential to the further study of the effects of global warming in the coastal system (Underwood and Keough, 2001).

Latitudinal variations in intertidal community dynamics and distribution have not been extensively studied in the Asian region. From the NW Pacific to the South China Sea, the intertidal area is colonized by a high diversity of barnacles including Chthamalus challengeri Hoek, $C$. malayensis Pilsbry, C. neglectus Yan and Chan, Tetraclita squamosa Bruguiere, T. kuroshioensis Chan, Tsang and Chu, T. japonica japonica Pilsbry, T. japonica formosana Hiro (Tsang et al., 2007; Chan et al., in press) and Megabalanus spp. (Ren and Liu, 1979; Yamaguchi, 1973, 1987; Kado and Hirano, 1994; Hasegawa et. al., 1996; Chan, 2001; Chan et al., 2007a, b). The distribution and abundance of barnacle species varies along the latitudinal gradient from Japan, Taiwan to Hong Kong. In the family Tetraclitidae, Tetraclita kuroshioensis was identified as a separate species from $T$. squamosa using molecular and morphological analysis in NW Pacific waters (Chan et al., 2007a, b). T. j. japonica and T. j. formosana are present on the Pacific coastline of Japan and Taiwan (Yamaguchi, 1987) whilst only T. squamosa and T. j. japonica occur in Hong Kong (Chan, 2001; Chan et al., 2001). In Japan, T. kuroshioensis and T. j. formosana co-exist in the same tidal level but $T$. j. japonica and $T$. squamosa occur in different zones in Hong Kong (Yamaguchi, 1987; Chan et al., 2001). It appears that variation in the climatic and oceanographic conditions along the latitudinal gradient affects the ecology and distribution of barnacles from the NW Pacific to the South China Sea although no studies have been conducted to address the geographical distribution and population dynamics of the intertidal communities on this scale in Asia. The present study investigates and reviews the ecology and distribution of intertidal barnacles in Hong Kong, Taiwan and Japan in an attempt to provide baseline information for further study of the latitudinal variation in Asian/NW Pacific intertidal waters.

\section{Sampling Locations and Methods}

Diversity and distribution pattern of rocky intertidal barnacles was studied in Hong Kong (Cape d'Aguilar), Taiwan (Badoutz and Taitung), Okinawa (Cape Teniya) and Honshu (Wakayama, Kii Peninsula and Kominato, Boso peninsula) in 2006 (Fig. 1).

Hong Kong is a tropical locale with strong seasonal climatic variation. Summer (April to October) is hot and wet (mean air temperature $30^{\circ} \mathrm{C}$ ) whilst winter (December to March) is cold and dry (mean air temperature $15^{\circ} \mathrm{C}$; Kaehler and Williams, 1996). In summer, under the influence of the S.E. monsoon, the Hong Kong waters are affected by the high temperature and high salinity of the South China Sea Current (Morton et al., 1996). In winter, the Hong Kong waters are influenced by the Taiwan and Kuroshio currents (Morton et al., 1996). The tides in Hong Kong are mixed semi-diurnal, often with 2 high tides and 2 low tides a day, and a maximum tidal range of 2.5 meters. Rocky shores in Hong Kong are primarily composed of hard and smooth granite or volcanic rocks (Morton and Morton, 1983).

Taiwan is divided into two climate regions, the sub-tropical north and the tropical south. The northern and eastern coastlines face the East China Sea and the Pacific Ocean respectively and are mainly composed of exposed rocky shores. The northern and eastern coastlines are influenced by the Kuroshio Current as it exits the Luzon Strait. The western coastline faces the Taiwan Strait and is 


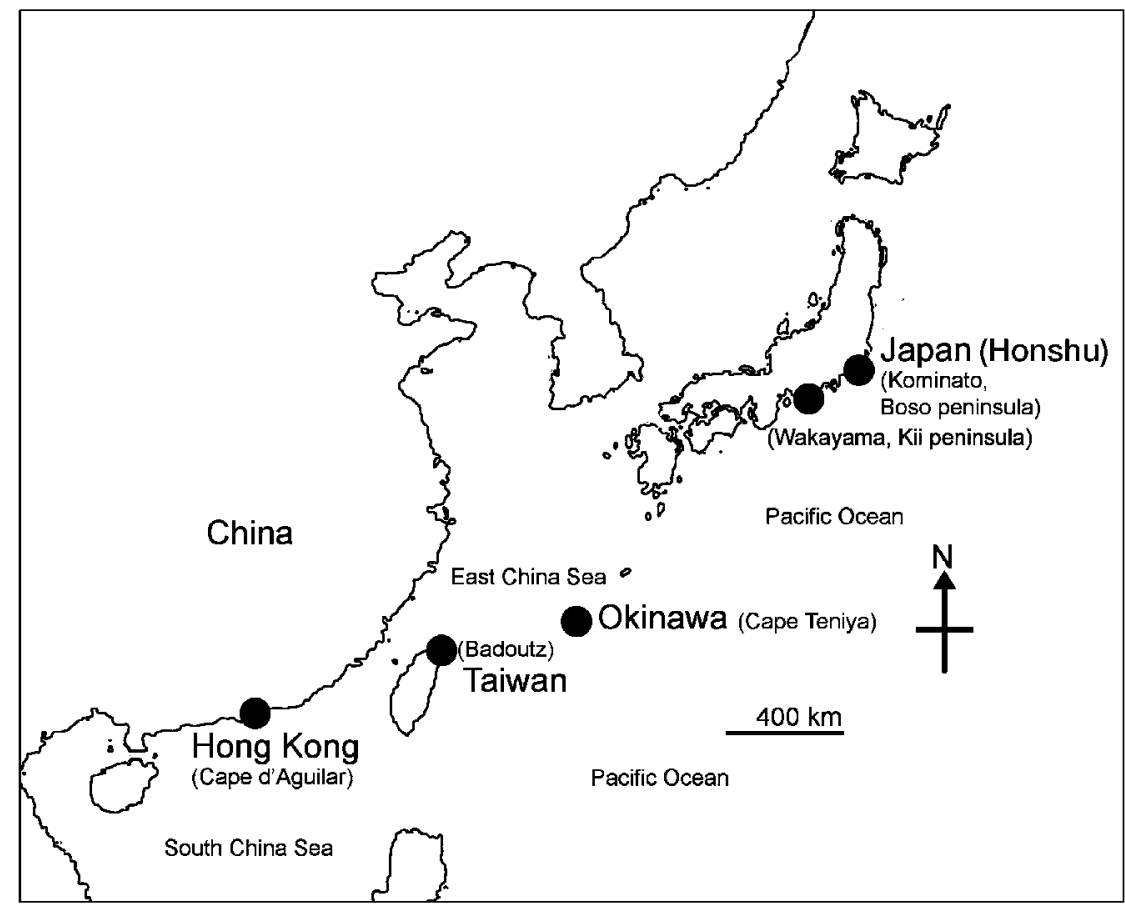

Fig. 1. Sampling location in the NW Pacific and S China region, including Honshu, Okinawa, Taiwan and Hong Kong.

mainly composed of sandy shores and mangroves.

The Pacific coastlines of the Honshu and Kyushu islands in Japan experience a temperate and sub-tropical climate respectively (Mori and Tanaka, 1989). The N.W. Pacific coastline in Japan is under the influences of the warm Kuroshio Current from the south and the cold Oyashio Current from the north.

Quantitative samplings on the abundance of barnacles were conducted in Japan, Taiwan and Hong Kong. At each location, a $30 \mathrm{~m}$ stretch of shoreline was chosen. At each shoreline, ten $25 \times 25$ $\mathrm{cm}$ quadrats were randomly selected (Chan et al., 2001) in the supralittoral zone $(2.5 \mathrm{~m}$ above Chart Datum, C.D.), high shore (2.0 $\mathrm{m}$ above C.D.), mid shore (1.5 $\mathrm{m}$ above C.D.) and low shore (1 $\mathrm{m}$ above C.D.). A digital photograph was taken for each quadrat and the barnacles inside the photographs were identified to species level and the percentage cover of each species was recorded.

\section{Results and Discussion}

\section{Biodiversity of rocky intertidal barnacles: Hong Kong, Taiwan, Japan} Hong Kong

On exposed rocky shores, barnacles exhibited distinct zonations. In the high shore, Chthamalus malayensis was common and their vertical range extended from the high shore (2.5 metres above Chart Datum, C.D.; Fig. 2) to the splash zone (3 metres above C.D.). Chthamalus malayensis had highest abundance at high shore level, with an average of $60 \%$ cover in Cape d'Aguilar (Figs 2, 3). The stalked barnacle, Capitulum mitella Linnaeus, colonized the crevices in the high shore and 
reached $\sim 40 \%$ cover in highly exposed locations (Leung, 2003; Figs 2, 3). In the mid-low shore, Tetraclita is the major common space occupier. Tetraclita japonica japonica occurred in the mid shores (1.25 - $2.25 \mathrm{~m}$ above C.D.) and had an average of $\sim 60 \%$ cover whilst $T$. squamosa was abundant at the low shore $(1-1.25 \mathrm{~m}$ above C.D.) and had an average of $\sim 20 \%$ cover on the shore (Figs 2, 3). Chthamalus neglectus (Yan and Chan, 2004a, b), a recently identified species, was abundant on the shell surfaces of the black mussel Septifer virgatus at the mid - low shore levels (Fig. $2)$. In the low shore, Megabalanus volcano Pilsbry was common ( $21 \%$ cover), often in association with the coralline algae Corallina spp. (Figs 2,3). In semi-exposed rocky shores, barnacle diversity was lower than in exposed shores. Chthamalus malayensis and Megabalanus volcano were absent from semi-exposed locations. Tetraclita squamosa and T. j. japonica were found in high abundance on the mid shore. Within the narrow crevices of semi-exposed and sheltered shores, the stalked barnacle Ibla cumingi Darwin (Fig. 2; Leung, 2003) and Chthamalidae barnacle Chinochthamalus scutelliforms Darwin colonized the habitat. In the estuarine waters and mangroves, Euraphia withersi and Fistulobalanus albicostatus Pilsbry were common species (Fig. 2) and they were often found on the tree trunks of mangroves (Chan and Leung, in press).

\section{Taiwan}

From the $\mathrm{N}$ to $\mathrm{NE}$ coastline, barnacles on the high shore included Hexechamaesipho pilsbryi (Hiro, 1938), Chthamalus moro (Southward and Newman, 2003) and C. malayensis (Figs. 2, 3). C. moro and $H$. pilsbryi were absent from Hong Kong. Abundance of C. malayensis in Taiwan was lower $(<10 \%)$ than Hong Kong (Fig. 3). In the mid shore, common space occupiers are the acorn barnacle Tetraclita kuroshioensis (Chan et al. 2007a, b) and T. j. formosana (Hiro, 1939), reaching 40 $\%$ cover on the shore. Tetraclita squamosa and T. j. japonica (present in Hong Kong) were absent from Taiwan (Fig. 3). Megabalanus volcano lived on the low shore of exposed locations (also see Hiro, 1939). Underneath the large boulders on semi-exposed shores, Tetraclitella multicostata and Tetraclitella chinensis occurred sparsely. On the west coast where salinity was lower and wave actions were reduced, Fistulobalanus albicostatus Pilsbry and Amphibalanus kodakovi Utinomi were common and they colonized the tree trunks and leaves of the mangroves (Fig. 2).

\section{Okinawa, Japan}

Barnacle composition in Okinawa was similar to Taiwan. Tetraclita kuroshioensis and $T . j$. formosana were the space occupiers in the mid and low shore. As different from Taiwan, the high shore of Okinawa was covered by Chthamalus malayensis, Hexechamaesipho pilsbryi and Nesochthamalus intertexta Darwin (Fig. 2). Inside the shaded crevices, Euraphia caudata Pilsbry was recorded.

\section{Honshu, Japan (Wakayama, Kii Peninsula and Kominato, Boso Peninsula)}

In Kominato and Wakayama, Chthamalus challengeri was the common high shore inhabitants, reaching $>60 \%$ mean cover on the shores. The stalked barnacles, Capitulum mitella, reached an average of $\sim 40 \%$ cover on the shores (Figs. 2, 3). In the mid shores, Tetraclita $j$ japonica and Tetraclita kuroshioensis reached $\sim 20 \%$ cover. T. j. japonica and T. kuroshioensis occurred at the same tidal level and did not exhibit clear zonations, notably different from the pattern of $T$. squamosa and T. j. japonica in Hong Kong (Fig. 3; also see Yamaguchi, 1987). Tetraclita japonica formosana was sparse in Kominato and Wakayama and the abundance was lower than that in Okinawa and Taiwan. Common rocky shore barnacles in Honshu, Okinawa and Taiwan were similar, except Chthamalus challengeri was the dominant high shore species along the Honshu coastline and was absent from Taiwan, Hong Kong and Okinawa. In Japan Chthamalus malayensis was rarely found (Yamaguchi, 1973, 1987; Kado and Hirano, 1994; Southward and Newman, 2003). Recently, Balanus glandula from the NE Pacific was identified in Japan; it has been identified as an invasive species and considered a potential risk to the geographical distribution of native barnacles (Kado, 2003). 


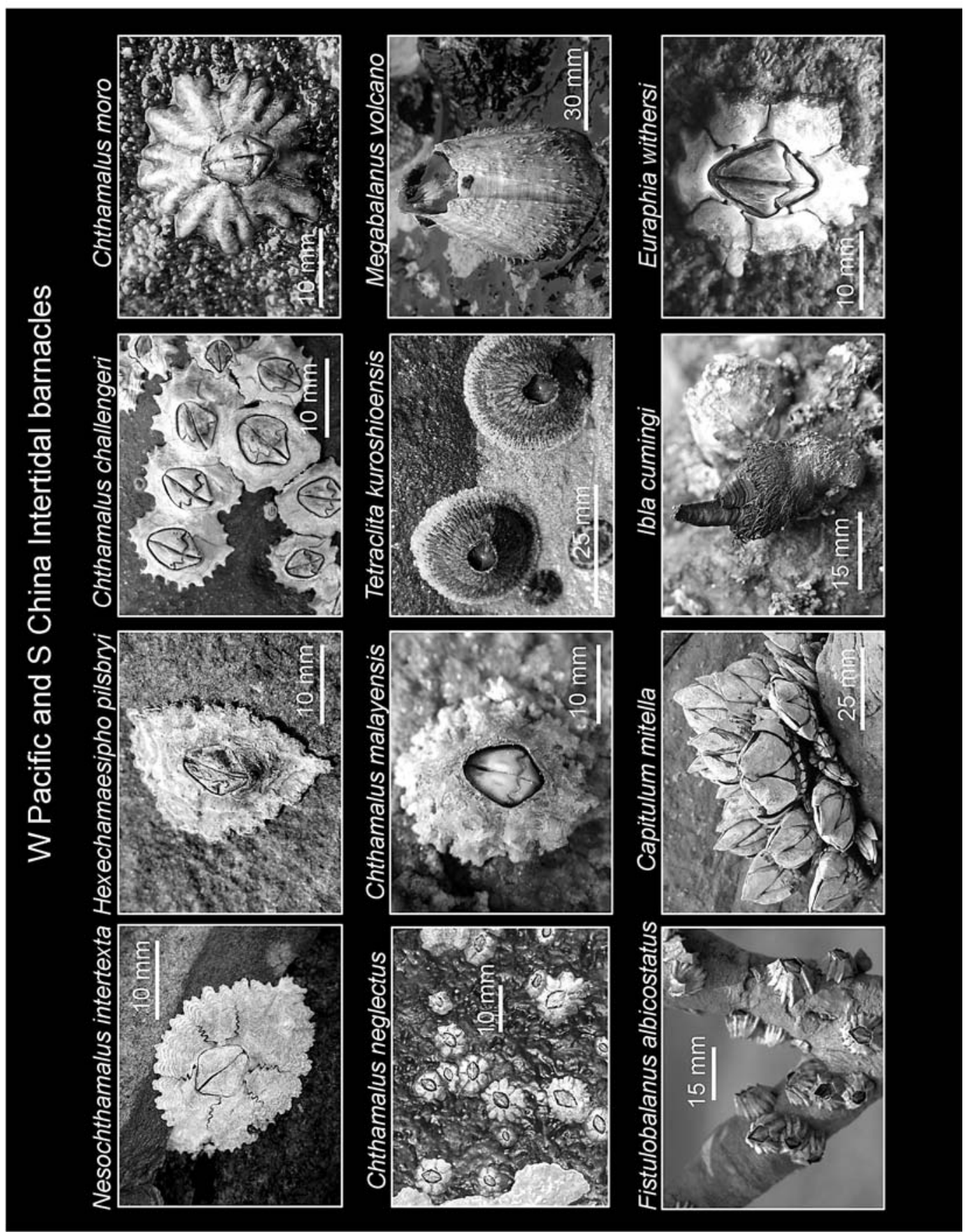

Fig. 2. Common rocky intertidal barnacles in the NW Pacific and S China Sea. 


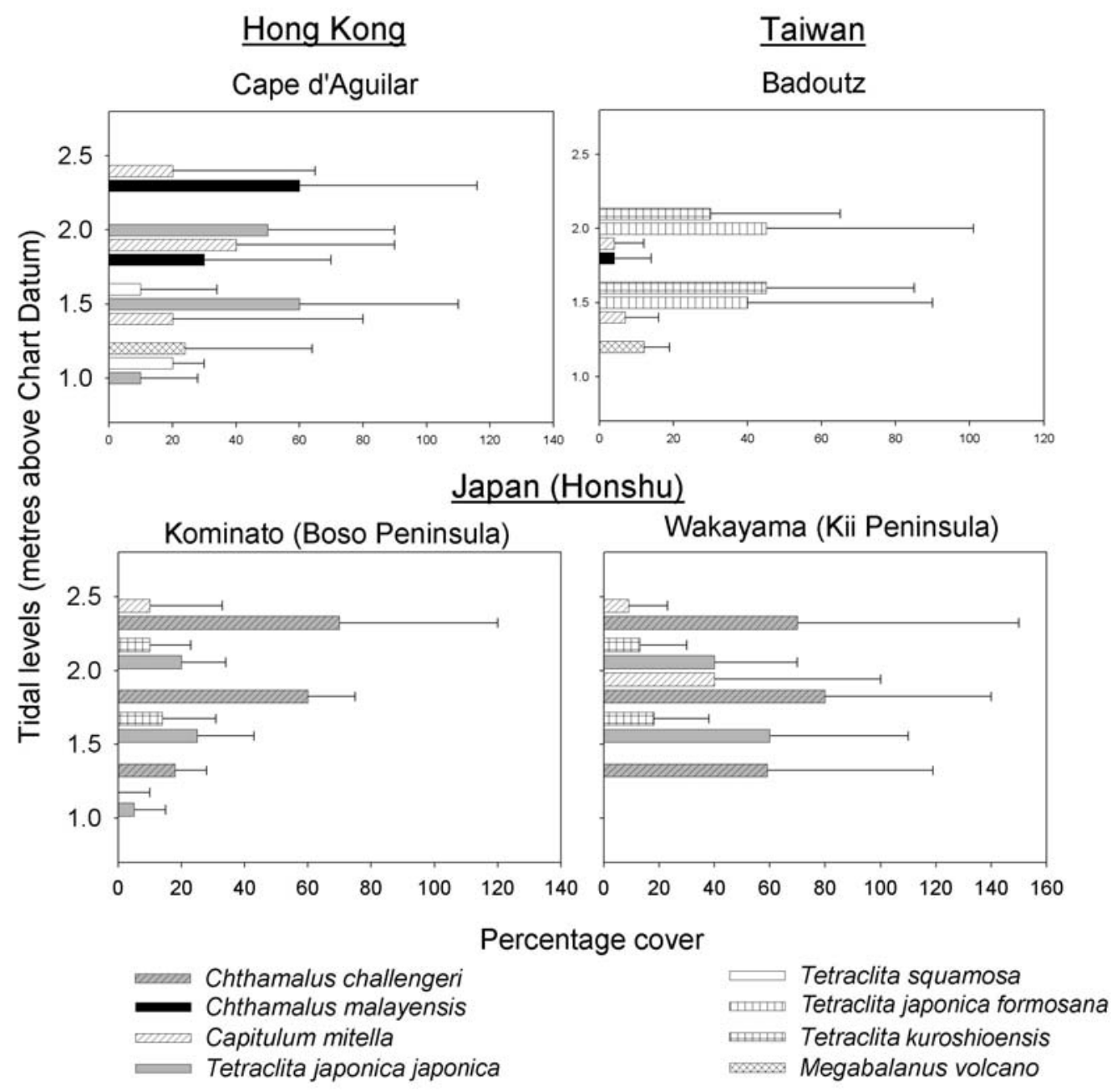

Fig. 3. Vertical distribution of barnacles (mean $+1 \mathrm{SD}, \mathrm{n}=10)$ in Hong Kong, Taiwan and Japan. At each site, a 30 metres transect was established at the 4 tidal levels (1, 1.5, 2 and 2.5 metres above C.D.) and ten random $25 \times 25 \mathrm{~cm}$ quadrats were established at each transect to measure the percentage cover of barnacles. Chthamalus moro (in Taiwan), Tetraclita japonica formosana (Japan) and Hexechamaesipho pilsbryi (Japan) was also recorded on the shore, but due to low abundance, they are not presented in the graph.

Differences in the barnacle composition between Hong Kong and other NW Pacific locations appeared to be influenced by the oceanographic currents. In the NW Pacific, Tetraclita kuroshioensis was abundant, ranging from Japan to Fiji (Chan et al., 2007a). However, the distribution of Tetraclita squamosa was recorded in the S China coast and not in Japan and Taiwan (Chan et al., 2007a). The other Pacific species, Chthamalus moro, which was abundant in Taiwan and Okinawa, was absent from Hong Kong. The high shore barnacle Hexechamaesipho pilsbryi was present in Honshu, Okinawa and Taiwan but absent from Hong Kong and S China locations (Ren and Liu, 1984). Such patterns suggest that barnacle species in Hong Kong are associated with the South China Sea Current whilst the Kuroshio Current influences barnacles in Taiwan and Japan. 


\section{Review on the settlement and reproductive patterns of barnacles in Hong Kong and Japan}

Under strong seasonal climatic variation, the life history pattern of barnacles in Hong Kong follows a seasonal trend. High water temperature in summer appears to initiate the gonad development of barnacles and trigger the subsequent life history processes. Chthamalus malayensis had mature male gonads through the whole year and mature female gonads in the summer (July September) and a maximum number of 10 broods per year. Intense annual settlements of $C$. malayensis occured in October, following the summer reproductive season (Yan et al., 2006). The growth rate of $C$. malayensis was fast and new recruits reached sexual maturity in 6 months (Yan $e t$ al., 2006). On the mid shores, Tetraclita squamosa produced egg masses from May - June and annual settlement and recruitment occurred from June - July (Chan and Williams, 2004). In contrast, settlement and recruitment of T. j. japonica was sparse from March - May but intensified in July October. Mature gonads and egg masses were, however, only present from September - November, suggesting the larvae from the two settlement pulses originated from other geographical locations, and not just from the Hong Kong populations (Chan and Williams, 2004). In general, there were two or three clear cohorts in the populations (Chan and Williams, 2004). From population dynamics studies, the longevity of Chthamalus malayensis and Tetraclita were three to four years (Yan, 2003; Chan and Williams, 2004).

The stalked barnacle Capitulum mitella in Hong Kong had mature gonads in summer but exhibited three annual settlements (twice in winter and once in summer), revealing that larval supply come from multiple geographical locations (Leung, 2003). C. mitella in Hong Kong reached sexual maturity from $9-12$ months after settlement (rostral carinal length $\sim 14 \mathrm{~mm}$ ). Compared with the population of $C$. mitella in Fuzhou, China (located north of Hong Kong; Lin, 1993), the Fuzhou population had a lower growth rate and took two years to reach sexual maturity (Lin, 1993). In Fuzhou, only one annual settlement was recorded different from Hong Kong where multiple settlements occurred (Lin, 1993; Leung, 2003). In Hong Kong, the stalked barnacle Ibla cumingi which lives in fine crevices had mature gonads year round with a peak reproductive season in summer (Leung, 2003). Settlement and recruitment of I. cumingi occurred continuously throughout the year (Leung, 2003).

Comparing the reproductive patterns of barnacles in Hong Kong and Japan, the reproductive period of barnacles appeared to shorten with an increase in latitude (see also Kosaka and Ishibashi, 1979; O' Riordan et al., 2004). In Japan, the reproductive period of the stalked barnacle, Capitulum mitella, lasted for three months (Yoshino and Konno, 1987) whilst C. mitella in Hong Kong had mature gonads for five or six months (Leung, 2003). Comparing the annual reproductive patterns of Chthamalus malayensis in Hong Kong and C. challengeri in Japan, C. malayensis generally had four or five peaks of brooding individuals whilst $C$. challengeri had 2 peaks of brooding individuals (Mori, 1986; Yan et al., 2006). These differences in barnacle growth rate and reproductive patterns can be influenced by the variation in seawater temperature along the latitude (see Hines, 1978; Murata et al., 2001; O'Riordan et al., 2004).

Intertidal barnacles in Hong Kong suffered high mortality during the hot summer and such huge mortality has not been reported in higher latitude temperate shores. During summer in Hong Kong the maximum air temperature can reach $32^{\circ} \mathrm{C}$, which can correspond to a rock surface temperature of $50^{\circ} \mathrm{C}$ (Williams, 1994; Williams and Morritt, 1995; Chan and Williams, 2003; Williams et al., 2006). In such intense heat the desiccation and stress caused intense mortality of adult populations of Tetraclita japonica japonica in the high shore level of exposed shores (Chan et al., 2006). The maximum body temperature of $T . j$. japonica in summer reached $50^{\circ} \mathrm{C}, 8^{\circ} \mathrm{C}$ higher than the rock surface temperature (Chan et al., 2006), indicating the high shore populations underment severe heat stress. However, after the intense mortality events in summer, populations of $T$. j. japonica regularly received recruits in 
late summer, which replenished the population lost during the harsh summer months (Chan et al., 2001).

\section{Summary}

Barnacles along the latitude from Japan to Hong Kong experience a gradient of environment stresses and different currents. In the temperate island of Honshu and the sub-tropical islands of Kyushu on northern Taiwan, barnacles appear to have lower growth rates, lower mortality and reduced reproductive output when compared to the tropical island of Hong Kong. In Hong Kong, due to higher temperatures, barnacles have a faster growth rate, shorter longevity and invest more energy in reproduction. The effect of latitude is obvious in the species richness of the intertidal assemblages (Hokkaido to Kyushu - Okuda et al., 2004) and within intertidal single taxa (Honshu to Hong Kong present study). To further study the effect of latitude on the life history pattern and persistence of intertidal organisms such as barnacle simultaneous studies on larval supply (Minchinton, and Scheibling, 1991; Yan et al., 2004; see also Schiel, 2004), population dynamics and reproductive biology from the whole latitudinal gradient will be needed.

\section{Acknowledgements}

The author would like to thank the NAGISA organizing committee for the financial support to attend the International Near Shore Biodiversity Symposium. This paper is partly supported by a Taiwan National Science Grant, and research and travel grants in Academia Sinica. The author would like to thank Prof. T. Yamaguchi and Romanus Prabowo (Chiba University, Japan), A. Murata (Natural History Museum and Institute, Chiba) and H. Fukami (Seto Marine Biological Laboratory, Kyoto Uiversity) for their support in the research conducted in Japan. Thanks to C-H Hsu and Y-C Fan (Academia Sinia) for the assistance in field work in Hong Kong.

\section{References}

Chan, B.K.K. 2001. Studies on Tetraclita squamosa and Tetraclita japonica (Cirripedia: Thoracica) I: adult morphology. Journal of Crustacean Biology, 21, 616-630.

Chan, B.K.K. and Williams, G.A. 2003. Effect of physical stress and mollusc grazing on the settlement and recruitment of Tetraclita species on a tropical shore. Journal of Experimental Marine Biology and Ecology, $283,1-23$

Chan, B.K.K. and Williams, G.A. 2004. Population dynamics of the acorn barnacles, Tetraclita squamosa and Tetraclita japonica (Cirripedia: Balanomorpha) in Hong Kong. Marine Biology, 146, 149-160.

Chan, B.K.K. and Leung, P.T.Y. (in press) Antennular morphology of the cypris larvae of the mangrove barnacle Fistulobalanus albicostatus (Cirripedia: Thoracica: Balanomorpha). Journal of the Marine Biological Association of the United Kingdom.

Chan, B.K.K., Morritt, D. and Williams, G.A. 2001. Effect of salinity and recruitment on the distribution of Tetraclita squamosa and Tetraclita japonica (Cirripedia: Balanomorpha) in Hong Kong. Marine Biology, 138, 999-109.

Chan, B.K.K., Tsang, L.M. and Chu, K.H. 2007a. Morphological and genetic differentiation of Tetraclita in E Asia: description of a new species of Tetraclita. Zoological Scripta, 36, 79-91.

Chan, B.K.K., Tsang, L.M. and Chu, K.H. 2007b. Cryptic deversity of the Tetraclita Squamosa complex (Crustasea: Cirripedia) in Asia: Description of a new species from Singapore. Zoological Studies, 46, 46-56.

Chan, B.K.K., Tsang, L.M, Ma, K.Y, Hsu C-H and Chu, K.H (in press). Taxonomic revision of the acorn barnacles Tetraclita japonica and Tetraclita formosana (Cruotace: Cirripedia) in East Asia based on molecular and morphological analysis. Bulletin of Marine Science.

Chan, B.K.K., Morritt, D., Depirro, M., Leung, K.M.Y. and Williams, G.A. 2006. Summer mortality: impacts on the distribution and abundance of the barnacle Tetraclita japonica on tropical shores. Marine Ecology Progress Series, 328, 195-204.

Connolly, S.R., Menge, B.A. and Roughgarden, J. 2001. A latitudinal gradient in recruitment of intertidal 
invertebrates in the northeast Pacific Ocean. Ecology, 82, 1799-1813.

Hasegawa, T., Yamaguchi, T., Kojima, S. and Ohta, S. 1996. Phylogenetic analysis among three species of intertidal barnacles of the genus Tetraclita (Cirripedia: Balanomorpha) by nucleotide sequences of a mitochondria gene. Benthos Research, 51, 33-39.

Hines, A.H. 1978. Reproduction in three species of intertidal barnacles from central California. Biological Bulletin, 154, 262-281.

Hiro, F. 1938. Description of three new species of Cirripedia from Japan. Bulletin of the Biogeographical Society of Japan, 6, 221-230.

Hiro, F. 1939. Studies on the cirripedian fauna of Japan IV: Cirripedes of Formosa (Taiwan) with some geographical and ecological remarks on the littoral forms. Memoirs of the College of Science, Kyoto Imperial University, Series B, 15, 245-284.

Jenkins S.R., Aberg, P., Cervin, G., Coleman, R.A., Delany, J., Hawkins, S.J., Hyder, K., Myers, A.A., Paula, J., Power, A.M., Range, P. and Hartnoll, R.G. 2001. Population dynamics of the intertidal barnacle Semibalanus balanoides at three European locations: spatial scales of variability. Marine Ecology Progress Series, 217, 207-217.

Kaehler, S. and Williams, G.A. 1996. Distribution of algae on tropical rocky shores: spatial and temporal patterns of non-coralline encrusting algae in Hong Kong. Marine Biology, 125 (1), 177-187.

Kado, R. 2003. Invasion of Japanese shores by the NE Pacific barnacle Balanus glandula and its ecological and biogeographical impact. Marine Ecology Progress Series, 249, 199-206.

Kado, R. and Hirano, R. 1994. Larval development of two Japanese Magalaninae barnacles, Megabalanus volcano and Megabalanus rosa (Cirripedia: Balanidae), reared in the laboratory. Journal of Experimental Marine Biology and Ecology, 175, 17-41.

Kawai, T. and Tokeshi, M. 2004. Variable modes of facilitation in the upper intertidal: goose barnacles and mussels. Marine Ecology Progress Series, 272, 203-213.

Kosaka, M. and Ishibashi, I. 1979. The breeding, settlement, growth and survival of the acorn barnacle Tetraclita squamosa japonica in the Shimizu Harbour. Journal of the Faculty of Marine Science and Technology of the Tokai University, 12, 191-208.

Leung, T.Y. 2003. The ecology and reproductive biology of two intertidal barnacles, Capitulum mitella and Ilba cumingi (Cirripedia: Pedunculata) in Hong Kong. Ph.D. Thesis, The University of Hong Kong, Hong Kong.

Lin, G. 1993. A preliminary study on the reproductive biology of Pollicipes mitella. M.Phil. Thesis. Fujian Normal University.

Minchinton, T.E. and Scheibling, R.E. 1991. The influence of larval supply and settlement on the population structure of barnacles. Ecology, 72, 1867-1879.

Morgan, S.G. 2001. The larval ecology of marine communities. In, Bertness M.D., Gaines, S.D. and Hay M.E. (eds). Marine Community Ecology. Sinauer Associates, Inc. Sunderland, Masschusetts, pp. 159-181.

Mori, K. 1986. Life history and its variation of an intertidal barnacle, Chthamalus challengeri Hoek (Preliminary report). Benthos Research, 29, 51-57.

Mori, K. and Tanaka, M. 1989. Intertidal community structures and environmental conditions of exposed and sheltered shores in Amakusa, Japan. Publications of the Amakusa Marine Biological Laboratory, 10, 41-64.

Morton, B. and Morton, M. 1983. Seashore Ecology of Hong Kong. Hong Kong University Press.

Morton, B., Williams, G.A. and Lee, S.Y. 1996. The benthic marine ecology of Hong Kong: a dwindling heritage? In, Coastal infrastructure development in Hong Kong: a review. Proceedings of the Symposium on Hydraulics of Hong Kong Waters, Hong Kong 1995. Hong Kong, the Office, pp. 233-268.

Murata, A., Imafuku, M. and Abe N. 2001. Copulation by the barnacle Tetraclita japonica under natural conditions. Journal of Zoology, 253, 275-280.

Okuda, T., Noda, T., Yamamoto, T., Ito, N. and Nakaoka, M. 2004. Latitudinal gradient of species diversity: multi-scale variability in rocky intertidal sessile assemblages along the Northwestern Pacific Coast. Population Ecology, 46, 159-170.

O’Riordan, R.M., Arenas, F., Arrontes, J., Castro, J.J., Cruz, T., Delany, J., Martinez, B., Fernandez, C., Hawkins, S.J., McGrath, D., Myers, A.A., Oliveros, J., Pannaccilulli, F.G., Power, A.M., Relini,G., Rico, J.M. and Silva, T. 2004. Spatial variation in the recruitment of the intertidal barnacles Chthamalus montagui Southward and Chthamalus stellatus (Poli) (Crustacea: Cirripedia) over an European scale. Journal of Experimental Marine Biology and Ecology, 304, 243-264. 
Ren, X. and Liu, R. 1979. Studies on Chinese Cirripedia (crustacean) II: Family Tetraclitidae. Oceanologia et Limnologia Sinica, 10, 338-353.

Ren, X. and Liu, R. 1984. Studies on Chinese Cirripedia (crustacean) III: Family Chthamalidae. Studia Marina Sinica, 22, 145-163.

Reimer, A.A. 1976a. Description of a Tetraclita stalactifera panamensis community on a rocky intertidal Pacific shore of Panama. Marine Biology, 35, 225-238.

Reimer, A.A. 1976b. Succession of invertebrates in vacant tests of Tetraclita stalactifera panamensis. Marine Biology, 35, 225-238.

Southward, A.J. and Newman, W. 2003. A review of some common Indo-Malayan and western Pacific species of Chthamalus barnacles (Crustacea: Cirripedia). Journal of the Marine Biological Association of the United Kingdom, 83, 797-812.

Schiel, D.E. 2004. The structure and replenishment of rocky shore intertidal communities and biogeographic comparisons. Journal of Experimental Marine Biology and Ecology, 300, 309-342.

Thompson, R.C., Crowe, T.P. and Hawkins, S.J. 2002. Rocky intertidal communities: past environmental changes, present status and predictions for the next 25 years. Environmental Conservation, 29, 168-191.

Tsang, L.M., Chan, B.K.K., Ma, K.Y, Hsu C-H and Chu, K.H. 2007. Lack of mtDNA and morphological differentiation between two acorn barnacle Tetraclita japonica and $T$. formosana differing in parietes colours and geographical distribution. Marine Biology 151, 147-155.

Underwood, A.J. and Keough, M.J. 2001. Supply-side ecology, the nature and consequences of variation in recruitment of intertidal organisms. In, Bertness M.D., Gaines, S.D. and Hay M.E. (eds). Marine Community Ecology. Sinauer Associates, Inc. Sunderland, Masschusetts, pp. 183-200.

Williams, G.A. 1994. The relationship between shade and molluscan grazing in structuring communities on a moderately-exposed tropical rocky shore. Journal of Experimental Marine Biology and Ecology, 178, 79-85.

Williams, G.A., and Morritt, D. 1995. Habitat partitioning and thermal tolerance in a tropical limpet, Cellana grata. Marine Ecology Progress Series, 124, 89-193.

Williams, G.A., Pirro, M.D., Leung, K.M.Y. and Morritt, D. 2006. Physiological responses to heat stress in a tropical limpet, Cellana grata, the benefits of mushrooming behaviour. Marine Ecology Progress Series, 292, 213-224.

Yamaguchi, T. 1973. On Megabalanus (Cirripedia, Thoracica) of Japan. Publications of Seto Marine Biological Laboratory, 21, 115-140.

Yamaguchi, T. 1987. Changes in the barnacle fauna since the Miocene and the infraspecific structure of Tetraclita in Japan (Cirripedia: Balanomorpha). Bulletin of Marine Science, 41, 337-350.

Yan, Y. 2003. The ecology of the high shore barnacle Chthamalus malayensis in Hong Kong. Ph.D. Thesis, The University of Hong Kong, Hong Kong.

Yan, Y. and Chan, B.K.K. 2004a. A new barnacle species Chthamalus neglectus sp. nov. (Cirripedia: Thoracica: Chthamalidae) in Hong Kong. Journal of the Marine Biological Association of the United Kingdom, 84, 133-138.

Yan, Y. and Chan, B.K.K. 2004b. Larval morphology of the newly identified barnacle Chthamalus neglectus (Cirripedia: Thoracica: Chthamalidae) in Hong Kong. Journal of Crustacean Biology, 24, 519-528.

Yan, Y., Chan, B.K.K. and Williams, G.A. 2004. A modified and simplified trap for quantifying the distribution and supply of plankton to rocky shores. Journal of Plankton Research, 26, 247-253.

Yan, Y., Chan, B.K.K. and Williams G.A. 2006. Reproductive development of the barnacle Chthamalus malayensis in Hong Kong: implications for the life history patterns of barnacles on seasonal, tropical shores. Marine Biology, 148, 875-887.

Yoshino, T. and Konno, K. 1987. Seasonal changes in maturity of gonads of the gooseneck barnacle, Pollicipes mitella. Journal of the Tokyo University of Fisheries, 74, 11-21. 